\title{
野菜の生産・輸送過程における環境負荷に関する 定量的評価
}

\author{
吉川直樹 1 - 天野 耕二2 - 島田 幸司 3 \\ 1立命館大学大学院 理工学研究科（†525-8577 滋賀県草津市野路東1-1-1） \\ E-mail:ec081018@se.ritsumei.ac.jp \\ 2正会員 立命館大学教授 理工学部 \\ E-mail:amano@se.ritsumei.ac.jp \\ 3 正会員 立命館大学教授 経済学部 \\ E-mail:shimada@ec.ritsumei.ac.jp
}

\begin{abstract}
日本国内で消費される野菜の生産および輸送に伴う環境負荷を詳細に把握することを目的として, 野菜 生産費用および，卸売市場・貿易データに基づいて直接・間接 $\mathrm{CO}_{2}$ 排出量を品目別（14種）・時期別・地 域別に推計し，栄養素の含有量を機能単位とする環境効率の比較を行った. 国産野菜の生産と輸送に伴う $\mathrm{CO}_{2}$ 排出量は全体で約 580 万トンであり, 野菜 $1 \mathrm{~kg}$ 当たりに換算すると生産で $280 \mathrm{~g}-\mathrm{CO}_{2}$, 輸送では $130 \mathrm{~g}-\mathrm{CO}_{2}$ の排出量となった. 品目別では, 根菜類の $\mathrm{CO}_{2}$ 排出量が比較的少なく, 果菜類の $\mathrm{CO}_{2}$ 排出量が多かった. 地 域別にみると, 野菜の自給率が高い地域で $\mathrm{CO}_{2}$ 排出量が少なくなる傾向が明確に示された. また, 輸入野

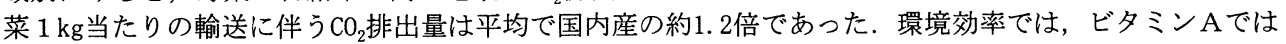
にんじん，ビタミンCやカリウムではだいこん（葉）やばれいしょの効率が高かった.
\end{abstract}

Key Words :vegetable production, $\mathrm{CO}_{2}$ emission, transportation, nutrient

\section{1. はじめに}

日本において食料の生産から消費に至る過程から発生 する環境負荷は，消費構造や生産・流通環境の変化によ り増加が䀣念されている. 農業分野における化石肥料・ 農薬の多用，施設栽培による化石燃料使用，運輸部門に おける高い自動車輸送分担率，食料自給率の低下による 輸入増等による輸送の長距離化は，いずれも環境負荷を 増大させる要因である.

これらの問題に対して, 近年では環境保全型農業の普 及や食料輸送距離(フードマイルズ)の削減や地産地消を 目指す運動も行われている.

既往の研究においては，農業生産における環境負荷の 研究（たとえば農業環境技術研究所 ${ }^{1)}$, 資源協会 ${ }^{2)}$ )の ほか, 食料システムにおけるマクロ的なエネルギ一消費 量の定量化 ${ }^{3)}$ や，東京卸売市場のデータを用いて品目 別・時期別に国内・海外からの野菜の輸送による環境負 荷を算出し，過去の時点との時系列的な比較を行った例 4) がある. しかし，ライフサイクル的な考えに基づいて 食料の生産と輸送を総合的に, かつ品目ごとに詳細に把 握した例はない.

そこで本研究では，日本において消費される野菜を対 象とし, 生産・輸送の各段階において発生する $\mathrm{CO}_{2}$ 排
出量について, 品目別・消費地域別, さらに部門別(家 計および加工・業務)に推計するとともに, 国内野菜に 関して, 栄養素の含有量を機能単位とした環境効率の比 較を行う.

\section{2. 研究手法}

本研究では, 野菜生産出荷安定法に基づいて定められ た指定野菜14種（表1）を対象として，定量評価を行っ た.この14種類の生産量で, 野菜全体の8割以上を占め る5) 6).

評価範囲は農業生産段階および産地から需要地までの 輸送段階とし(図1)，そこから直接的・間接的に発生す る二酸化炭素量を算出した．評価年は2003年とする．な お，それ以外の野菜はその他の野菜として一括して，14 品目のデータを外挿して野菜全体の負荷量を推計した.

さらに，各野菜に関して，栄養機能を考慮した指標と して, 主要栄養素の含有量あたりの $\mathrm{CO}_{2}$ 排出量を算出 し，品目間の比較を行った.

\section{（1）生産段階}

各野菜の生産段階における環境負荷は, 野菜・果樹品 目別統計 ${ }^{7)}$ の品目別・時期別の費目別生産費に $\mathrm{CO}_{2}$ 排 
表 1 対象野菜の概要

\begin{tabular}{|c|c|c|}
\hline 分類 & 品目 & $\begin{array}{c}\text { 国内生産量 } \\
(千 \mathrm{t})\end{array}$ \\
\hline \multirow{5}{*}{$\begin{array}{l}\text { 葉菱 } \\
\text { 菜類 }\end{array}$} & キャベツ & 1,179 \\
\hline & ほうれんそう & 251 \\
\hline & はくさい & 728 \\
\hline & ねぎ & 397 \\
\hline & レタス & 508 \\
\hline \multirow{2}{*}{$\begin{array}{l}\text { い } \\
\text { 類 }\end{array}$} & ばれいしょ & 2,401 \\
\hline & さといも & 125 \\
\hline \multirow{3}{*}{$\begin{array}{l}\text { 根 菜 } \\
\text { 類 }\end{array}$} & だいこん & 1,334 \\
\hline & にんじん & 576 \\
\hline & たまねぎ & 1,025 \\
\hline \multirow{4}{*}{$\begin{array}{l}\text { 果 菜 } \\
\text { 類 }\end{array}$} & きゅうり & 572 \\
\hline & なす & 293 \\
\hline & トマト & 669 \\
\hline & ピーマン & 129 \\
\hline
\end{tabular}

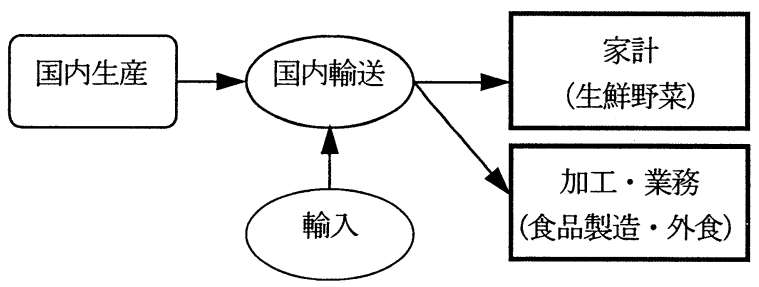

図 1 推計の対象範囲

表2 生産段階における $\mathrm{CO}_{2}$ 排出原単位

\begin{tabular}{|l|c|l|l|}
\hline \multicolumn{1}{|c|}{ 費目 } & $\begin{array}{c}\text { 原単位 } \\
\left(\mathrm{kg}-\mathrm{CO}_{2} / 千\right. \\
\mathrm{P})\end{array}$ & 資料 & \multicolumn{1}{|c|}{ 備考 } \\
\hline 種苗·苗木 & 1.3 & $11)$ & 種苗部門 \\
\hline 肥 料 & 8.3 & $11)$ & 化学肥料部門 \\
\hline 農業薬剂 & 4.8 & $11)$ & 農薬部門 \\
\hline 諸材料 & 3.0 & $11)$ & $\begin{array}{l}\text { 合成樹脂、製材·合板、 } \\
\text { その他の紙類の平均 }\end{array}$ \\
\hline 光熱動力 (露地) \\
(施設)
\end{tabular}

表3 輸送機関別 $\mathrm{CO}_{2}$ 排出原単位

比を計算した. 産業連関表では野菜に関して露地野菜と 施設野菜に分類されているため，両部門をともに算出し た. そこに農業物価統計 ${ }^{9}$ ににおける燃料の購入者価格 とエネルギー種別の二酸化炭素排出原単位 $\left.{ }^{100}{ }^{11}\right)$ を乗じ るととで費用あたりの排出原単位とした。

園芸施設費は，資源協会 ${ }^{2)}$ で設定された園芸施設の 一般的なモデルの諸元と物質投入量，および南齋ら ${ }^{11}$ の原単位より費用あたりの原単位を算定した.

それ以外の費用に関しては南齋ら ${ }^{11)}$ の値を用いた。 農用建物費に関しては木造建築部門と非木造建築部門の 原単位の中間值を，肥料費・農業薬剤費その他に関して は当該費目に最も適合する部門の原単位を用いた。

\section{（2）輸送段階}

輸送段階における $\mathrm{CO}_{2}$ 排出量は，根本 ${ }^{4)}$ を参考に， 式（1）のように定式化し，算出した.

$$
E_{i, n}=\sum_{j} \sum_{k} c_{k} r_{i, j, k} W_{i, j, n} L_{i, j, k}
$$

ここで, $E_{i, n}:$ 品目 $n$ の消費地 $i$ までの輸送にかかる 総二酸化炭素排出量

$L_{i, j, k}$ : 輸送機関 $k$ の場合の生産地 $j$ から消費地 $i$ ま での輸送距離

$W_{i, j, n}$ : 消費地 $i$ の品目 $n$ の消費における生産地 $j$ 産 品の重量

$r_{i, j, k}$ : 生産地 $j$ から消費地 $i$ までの輸送における輸送機 関 $\mathrm{k}$ の分担率

$c_{k}:$ 輸送機関 $k$ の二酸化炭素排出原単位

\begin{tabular}{|l|r|r|}
\hline 輸送機関 & $\begin{array}{c}\text { 原単位 } \\
\left(\mathrm{g}-\mathrm{CO}_{2} / \mathrm{t} / \mathrm{km}\right)\end{array}$ & \multicolumn{1}{l|}{ 資料 } \\
\hline 鉄道 & 22 & $10) 18)$ \\
\hline トラツク & 312 & $10) 18)$ \\
\hline 内航海運 & 38 & $10) 18)$ \\
\hline 外航海運 & 21 & $19)$ \\
\hline 航空 & 1,472 & $10) 18)$ \\
\hline
\end{tabular}

品目毎の消費都道府県別の産地割合（重量ベース）は， 青果物産地別卸売統計 ${ }^{12)}$ の消費地域別産地別の卸売市 場における取扱量から推計した。

輸送機関分担率は全国貨物純流動調査 ${ }^{13)}$ の農林水産 品の 3 日間調查における代表輸送機関別実績を基本とし, 同調査で実績のなかった都道府県間においては，他の品 類の值等を用いて補間した. 都道府県間距離は, トラッ ク輸送では地図ソフト ${ }^{14)}$ を，海運では距離表 ${ }^{15)}$ ，航空 輸送ではANA ${ }^{16)}$ ，J A L ${ }^{17)}$ のフライトマイレージを 用いて計測した。 なお，内陸県および空港のない都道府 県においては，海運・航空を代表輸送機関とする場合で も，近隣の港・空港からのトラック輸送を考慮している.

野菜の輸入に関しては, 輸入相手国の主要港から日本 までの距離 ${ }^{15)}$ より計算した. 国内のトラック輸送とし て，海に面する県においては設定した県内平均輸送距離 を内陸県においては近隣の主要港から県庁所在地までの 距離を用いた. したがって，輸入相手国内の国内輸送は 考慮されていない.

最後に, 平均輸送距離と, 輸送機関別の $\mathrm{CO}_{2}$ 排出原 
表4 野菜の都道府県間輸送量の推計結果と自動車輸送分担率

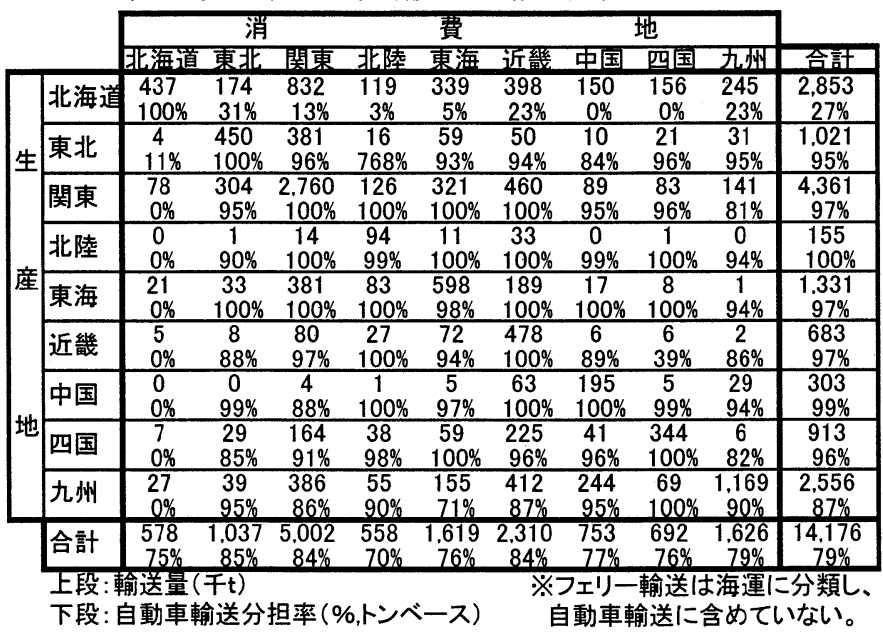

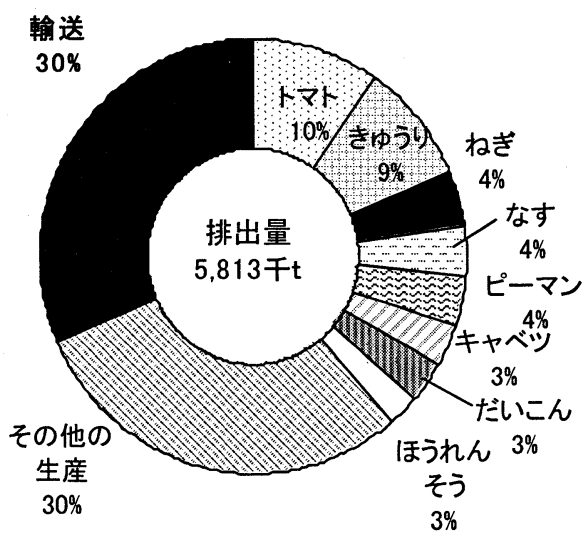

図2国産野菜の生産·輸送による $\mathrm{CO}_{2}$ 排出量

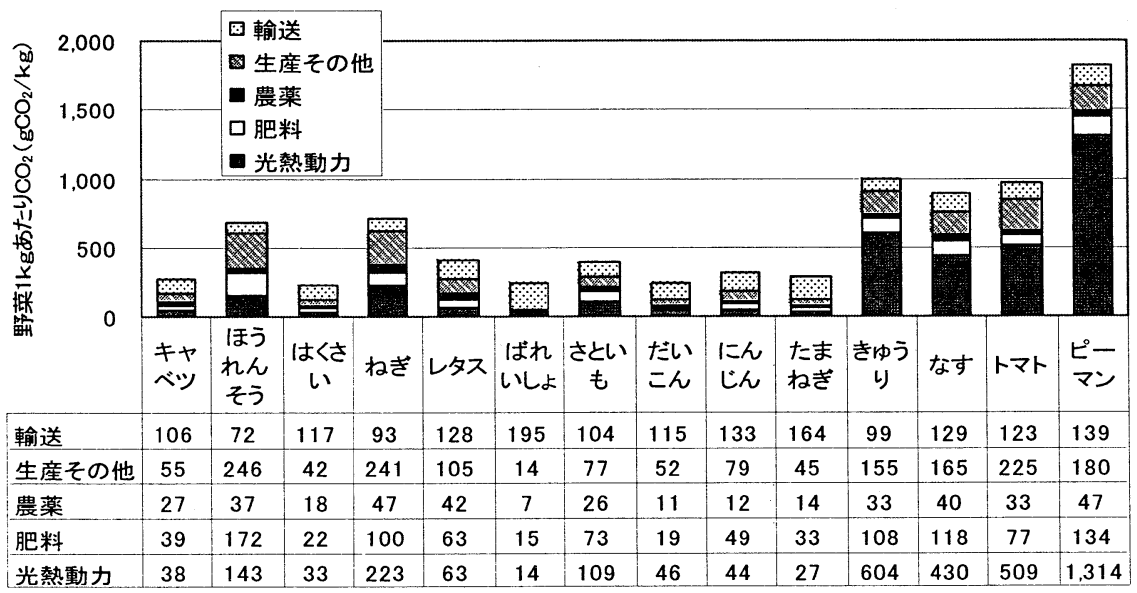

図3 野菜の品目別平均 $\mathrm{CO}_{2}$ 排出量

単位 18）19）（表 3）より，品目別消費都道府県別の野 菜輸送の重量あたりの $\mathrm{CO}_{2}$ 排出量が算出される.

（3）国内産野菜の消費による二酸化炭素排出量の推計

国内野菜の消費によって発生する二酸化炭素の総排出 量は，(1)の国内産野菜の生産 $\mathrm{CO}_{2}$ 排出量・輸送段階に おける消費都道府県別平均 $\mathrm{CO}_{2}$ 排出量と, さらに都道 府県別の需要量より求めることができる.

都道府県別の野菜需要量は, 家計需要および加工・業 務需要からなるとした. 家計需要は, 家計調査 ${ }^{20)}$ の総 世帯の都道府県庁所在地別の支出額と, 農林漁家世帯を 除< 2 人以上全世帯の都道府県庁所在地別支出額と購入 数量から求めた平均購入価格より総世帯の購入量を推計 した. その購入量に, 都道府県別の世帯数 ${ }^{21)}$ を乗じて 家計の都道府県別品目別需要とした. そのうち輸入品に 占める割合は, 青果物卸売市場調査報告 ${ }^{22)}$ の全卸売市 場における品目別の輸入割合を利用した. 加工・業務需 要は, 国内野菜出荷量と輸入量から輸出量と家計需要を 除いた量とした. この量を小林 ${ }^{23)}$ の推計による加工需 要・業務需要の全需要に占める割合（2000 年）から加 工需要と業務需要に分解し, 各部門の総需要量を都道府
県別の活動量（加工部門では工業統計 ${ }^{24)}$ の野菜缶詰・ 果実缶詰・農産保存食料品製造業, 漬物製造業, ソース 製造業，冷凍調理食品製造業，制菜製造業の生産額の合 計值，業務需要においては家計調査によって推計した都 道府県別外食支出額) で配分した. 加工・業務需要にお けるそれぞれの 2003 年の輸入割合は, 詳細なデータが 得られなかったため等しいと仮定し, 全体での総 $\mathrm{CO}_{2}$ 排出量を求めた. なお, じやがいもに関しては, 加工需 要を農林水産省 ${ }^{25)}$ の值とし, 出荷量から家計需要と加 工需要を除いたものを業務需要とした.

\section{（4）栄養素量を機能単位とした環境負荷指標}

栄養機能という面から野菜を見た場合, その大きな役 割は無機質およびビタミンの供給である. よって, 本研 究では，野菜に比較的多く含まれる無機質・ビタミンの 量を機能単位として, 含有量あたりの $\mathrm{CO}_{2}$ 排出量を指 標として算出した. 対象とする栄養素はビタミンA，ビ タミンCおよびカリウムである. 食品成分表 ${ }^{6)}$ の各品目 毎の重量あたり含有量の值と同表に記載されている各野 菜の非可食部の割合である廃棄率より以下のように算出 した. 


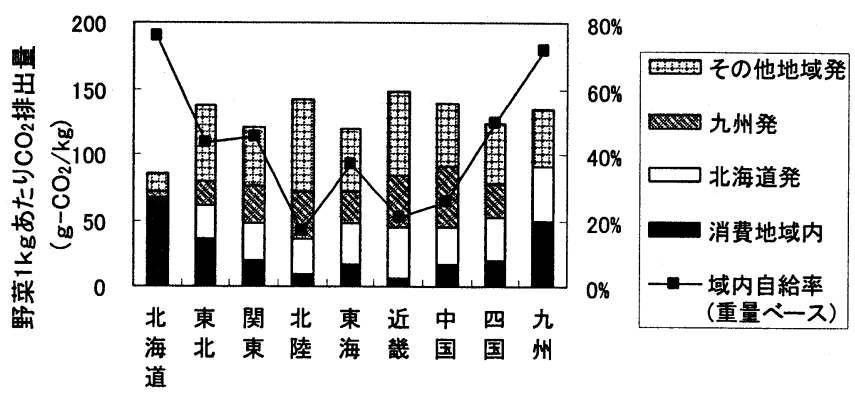

図4 消費地域別産地別の輸送 $\mathrm{CO}_{2}$ 排出量(国内産)

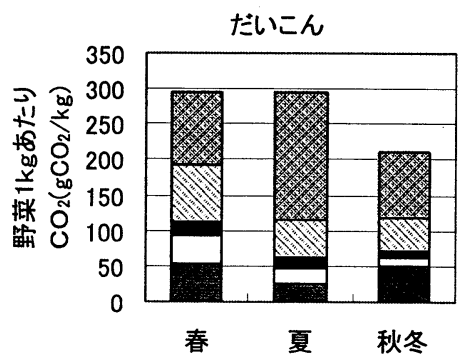

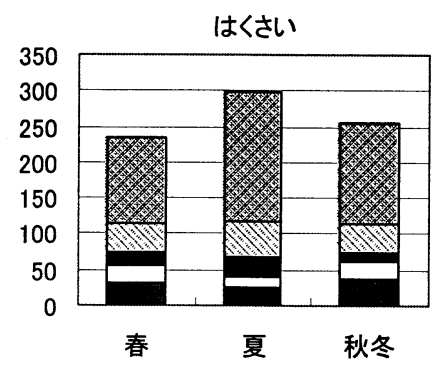

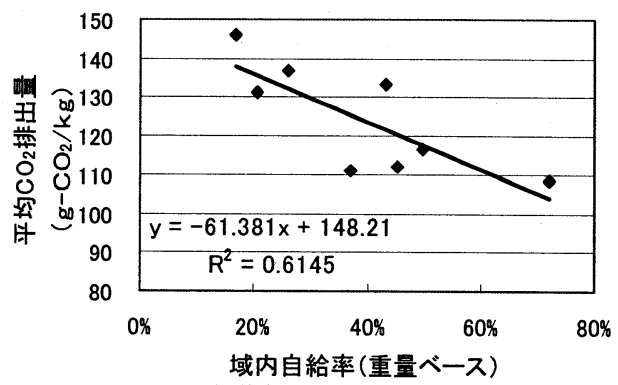

図5 北海道産以外の平均輸送 $\mathrm{CO}_{2}$ 排出量と 域内自給率の関係

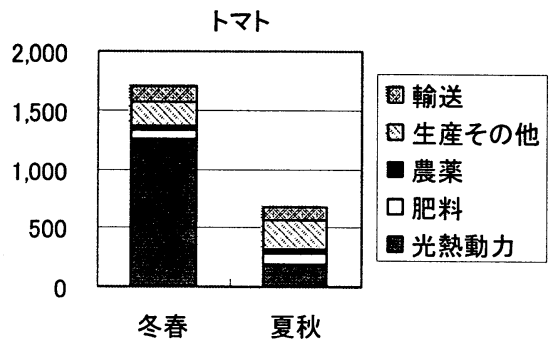

図6 品目別·季節別の重量あたりCO 2 排出量

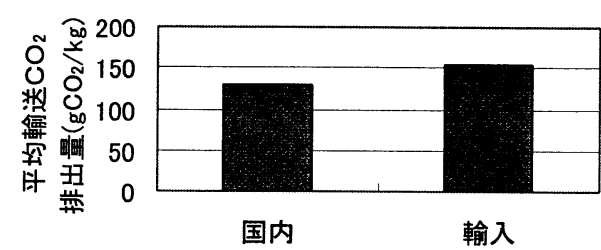

図7生産地別の平均輸送 $\mathrm{CO}_{2}$ 排出量

$$
f_{n}=\frac{e_{n}}{x_{n}\left(1-t_{n}\right)}
$$

ここで, $f_{n}$ : 品目 $n$ の栄養素量当たり $\mathrm{CO}_{2}$ 排出量

$e_{n}$ : 品目 $n$ の平均生産・輸送 $\mathrm{CO}_{2}\left(\mathrm{~g}-\mathrm{CO}_{2} / 100 \mathrm{~g}\right)$

$X_{n}$ : 品目 $n$ の可食部 $100 \mathrm{~g}$ あたり栄養素含有量

$t_{n}$ : 品目 $n$ の廃棄率.

\section{3. 推計結果}

\section{（1）輸送量と輸送分担率}

国内野菜の都道府県間輸送量の推計結果を，自動車輸 送の分担率（輸送量ベース）とともに表4に示す. 国産 野菜の2003年における国内消費量は14, 176千 t であり, うち35\%を関東地方において消費している. 生産に関し ては, 北海道, 千葉県・茨城県をはじめとする関東地方, 長崎県・熊本県などの九州で多い，用途別では，48\%を 家計需要が占め, 残りの $52 \%$ 加工・業務需要となった.

輸送機関分担率をみると, 北海道とその他の地域間の 輸送において，船舶や鉄道が多く利用されている. その ほか, 九州・四国と関東・東海・近畿の間でも比較的船 舶が利用されている.
（2）国内産野菜の生産・輸送全体の $\mathrm{CO}_{2}$ 排出量

国内で消費される国内産野菜の生産およひ輸送に関す る環境負荷は, 図2に示すように, 生産・輸送に関する 環境負荷は全体で5,813千 t であり，その内の7割が生産， 3割が輸送によるものとなった．生産の内訳を見ると， トマトやきゅうりなど施設栽培が広く行われている品目 の割合が高く，だいこんなど生産量の多い品目がそれに 次いで大きな割合を占めた. 重量あたりでは, 野菜 $1 \mathrm{~kg}$ あたりの生産 $\mathrm{CO}_{2}$ 排出量は279g- $-\mathrm{CO}_{2}$, 輸送段階では $128 \mathrm{~g}-$ $\mathrm{CO}_{2}$ となった.

\section{（3）品目別 $\mathrm{CO}_{2}$ 排出量}

図3は，野菜14品目の品目ごとの生産・輸送過程にお ける環境負荷（全国平均）である. 野菜 $1 \mathrm{~kg}$ の生産・輸 送に対して最も多くの二酸化炭素を排出しているのはピ 一マンであり，ばれいしょが最も低いことが分かった。 全体的にみると, 果菜類の $\mathrm{CO}_{2}$ 排出量が比較的多く, いも類・根菜類において低い. 施設栽培が広く行われて いる果菜類では光熱動力に伴う $\mathrm{CO}_{2}$ 排出量が多い. 一 方で, いも類・根菜類では生産段階において比較的低投 入であり，相対的に輸送に占める比率が大きい.

ばれいしょは，北海道や長崎から近畿や関東への長距 離の輸送量が多いため, 輸送のみに関しては14品中最も $\mathrm{CO}_{2}$ 排出量が多くなっている. ねぎやほうれんそうで は全国的に広く栽培が行われ，生産地域内で消費される 割合が高いことから，輸送に伴う $\mathrm{CO}_{2}$ 排出量は少ない. 

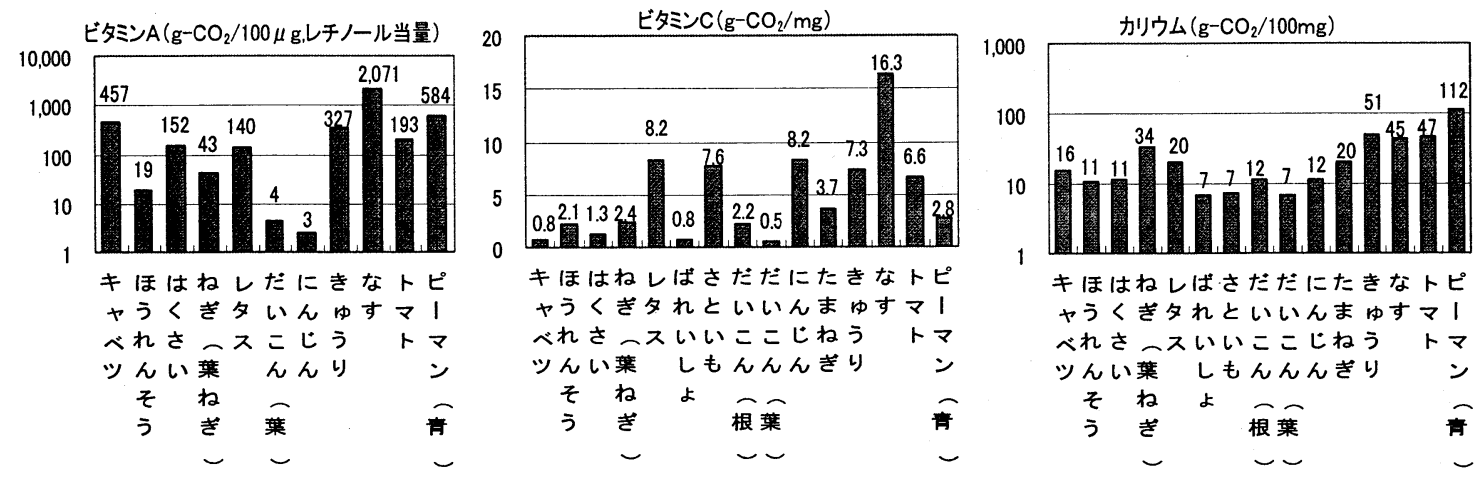

図8 主要栄養素含有量あたりのCO2排出量
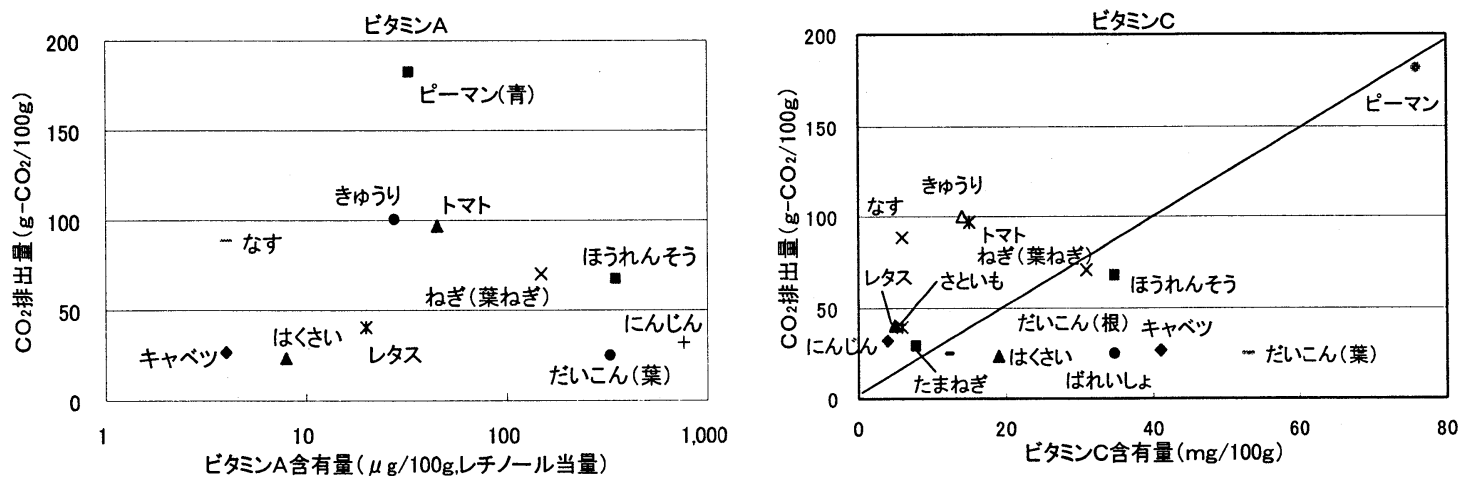

図9 品目別のビタミン含有量と可食部重量あたり $\mathrm{CO}_{2}$ 排出量の関係

\section{（4）消費地域別 $\mathrm{CO}_{2}$ 排出量}

消費地域別にみた野菜 $1 \mathrm{~kg}$ あたり生産・輸送全 $\mathrm{CO}_{2}$ 排 出量は, 北海道以外の地域では $531 \sim 580 \mathrm{~g}-\mathrm{CO}_{2} / \mathrm{kg}$ の範囲 に, 北海道では $455 \mathrm{~g}-\mathrm{CO}_{2} / \mathrm{kg}$ となった. 生産・輸送 $\mathrm{CO}_{2}$ は消費野菜の品目構成と産地加の距離・輸送手段の影 響を受けるが，北海道においてはばれいしょ・たまねぎ といった重量あたり $\mathrm{CO}_{2}$ 排出量の比較的小さい品目の 消費が多いことと, 後述のように輸送 $\mathrm{CO}_{2}$ も地域中最 も小さかったことからこのような結果となった.

図4に，消費地域別の国内産野菜消費 $1 \mathrm{~kg}$ あたりの平均 輸送 $\mathrm{CO}_{2}$ 排出量を示す. 図内の域内自給率は，地域の 野菜消費全体に占める自地域内産の割合 (重量ベース) である. 全国9地域中最も輸送 $\mathrm{CO}_{2}$ 排出量が少ないのは 北海道であり，最も多いのは近畿地方という結果となっ た. 北海道において少ないのは，じゃがいもやたまねぎ をはじめとした野菜生産量自体が多いために域内自給率 が高く, 平均輸送距離が短くなっていることと, 他地域 からの輸送においても海運や鉄道の利用度が高いことが 挙げられる. 近畿地方における排出量の多さは, 域内自 給率の低さに加え，自動車輸送がより多く利用されてい るためである.

北海道からの野菜輸送に関しては，表4が示すように 北海道産の消費量がどの地域においても全体の 15 23\% 程度と, 北海道からの距離にかかわらず一定の割合を占
めていることがわかった. よって, 北海道からの野菜輸 送の $\mathrm{CO}_{2}$ は、現在の消費パターンにおいては，域内自 給率との関係性は小さく, 消費地域からの距離と輸送機 関の分担率に大きく依存すると考えられる．北海道産以 外の野菜輸送に関しては，図4の域内自給率と重量あた り平均輸送 $\mathrm{CO}_{2}$ 排出量との間に比較的高い相関がみられ た(図5)。

\section{(5) 品目別 · 時期別 C $O_{2}$ 排出量}

季節ごとの環境負荷の変化を品目別に分析した結果が 図6である.だいこん・はくさいはともに冬，トマトは 夏が旬とされている野菜である.

結果を見ると，だいこんやトマトでは，旬の時期にお いて最も環境負荷が低くなっている.

まず，だいこんに関しては，輸送段階においては春・ 秋冬においては夏よりもかなり $\mathrm{CO}_{2}$ 排出量は少ない. 全国的に広く栽培される秋冬の輸送 $\mathrm{CO}_{2}$ 排出量は主に 北海道で栽培されている夏に比べ約50\%となっている. 生産に関しては春季の光熱動力や肥料等の投入量が多く, $\mathrm{CO}_{2}$ 排出量が多くなる結果となった.

はくさいでは, 四季を通じて生産 $\mathrm{CO}_{2}$ 排出量に大き な差はないが，輸送においては，だいこんと同様の傾向 がみられる. はくさいは夏季には主に長野・北海道・群 馬などの特定の泠涼地が大部分となるために他の時期に 
比へ輸送 $\mathrm{CO}_{2}$ 排出量は多い.

トマトに関しては，冬春の施設栽培に伴う暖房等の 光熱動力による排出量の差が大きい. その差に比べて 少ないものではあるが，輸送の面でも夏秋トマトのほ うが輸送 $\mathrm{CO}_{2}$ 排出量は少ない.

\section{(6) 野菜輸入に伴う輸送 $\mathrm{CO}_{2}$ 排出量}

野菜輸入に伴う $\mathrm{CO}_{2}$ 排出量は, $1 \mathrm{~kg}$ あたり $153 \mathrm{~g}-\mathrm{CO}_{2}$ と, 国産野菜に比べて1.2倍という結果となった（図7）。

輸入による平均輸送距離は6, $600 \mathrm{k} \mathrm{m}$ と国内輸送に比べ はるかに長いものの, 海運のエネルギー効率の高さか らこのような結果になった. この值には前述の通り輸 入相手国内の輸送は含まれていないため, 実際にはこ れよりも差は大きくなる.

この差は根菜類等の比較的低投入型の野菜では $\mathrm{CO}_{2}$ 排出量全体からみて小さくない割合を占めるが，果菜 類においてはそれほど大きな意味のある差ではない. この結果は, 輸入相手国の栽培状況によるものの，同 一の栽培方法を仮定した場合, 旬の時期以外において 果菜類を国内生産するよりも露地栽培での生産が可能 な国からの長距離輸送を行う方が環境負荷が低くなる 可能性を示唆している.

\section{（7）栄養素を機能単位とした環境負荷指標}

図8は，各野菜の栄養素含有量あたりの $\mathrm{CO}_{2}$ 排出量を 示している.この值が低いほど環境面における効率が 高いことを示す. 図9では各野菜のビタミン含有量と重 量あたりの環境負荷をプロットしている. ビタミンA の効力を表す指標としてはその1種であるレチノールの 量に換算したものであるレチノール当量の值を用いた. ビタミンAでは緑黄色野菜に分類されるにんじんや だいこん (葉)，ほうれんそうにおいて環境効率が高 いことがわかる，一方，緑黄色野菜ではない，なすや キャベツでは効率が低い.また, 緑黄色野菜の中でも ビタミンAの含有量が低く, 生産における環境負荷の 多いトマトやピーマンの環境効率は低い水準となった。

ビタミンCにおいては, ばれいしょ, キャベツ，だ いこん（葉），はくさいにおいて特に効率が高く，な すやきゅうり，トマト，レタスにおいて効率が低い. なすやレタスはビタミンCの含有量が低いことで, ト マトやきゅうりは重量あたりの環境負荷が高いために このような結果となった. 重量あたりの $\mathrm{CO}_{2}$ 排出が最 も多かったピーマン (青) は, ビタミンC量が14品目 中最も多いために環境効率が低くはなっていない.

カリウムにおいては含有量でみるとほうれんそう (690mg/100g)やさといも (640m g / $100 \mathrm{~g})$ が多かったが, 含有量あたりのC $\mathrm{C}_{2}$ 排出量では, さといもやばれいし ょ (410mg/100g)；だいこん(葉) $(400 \mathrm{mg} / 100 \mathrm{~g})$ の効率が高
いという結果となった. 最も含有量の少ないピーマン

（青） $(190 \mathrm{mg} / 100 \mathrm{~g})$ が最も環境効率が低かった.

以上のように栄養素との関係からの環境効率をみて きたが，効率を考える際には食物の1日あたりの摂取可 能量には上限があることにも注意が必要である．図9よ り, ビタミンAについては環境効率の高い野菜は重量 あたりの含有量が高い野菜であることが分かるが，ビ タミンCに関しては必ずしもそうはいえない，環境面 において効率が同じであっても，含有量の低い野菜で は十分な栄養素を摂取するのに大量に食べる必要があ り，それは現実的ではないといえる.

また，注意すべき第2の点として，特にビタミン類は 調理方法によって残存率や体内一の吸収率に大きな違 いがあるということがある. それによって，環境効率 に大きな変化がある可能性もある．また，ここで用い た $\mathrm{CO}_{2}$ 排出量の值は年間平均值であり, 先にみたよう な季節変動もあることも考慮する必要がある.

\section{4. まとめ}

本研究では, 日本で消費される国内産野菜について, 生産費データ・卸売市場データを用いて品目別・時期 別・消費地別に生産・輸送による $\mathrm{CO}_{2}$ 排出量を推計し た. また, 野菜輸送に関して国内産と海外産を比較し, 国内産野菜に関しては栄養素を機能単位とする環境負 荷の品目別比較を行った.

その結果, 次の点が明らかとなった.

(1)2003年における野菜の生産・輸送時における $\mathrm{CO}_{2}$ 排出量のうち輸送が30\%を占める. 全体では $5813 千 \mathrm{t}-$ $\mathrm{CO}_{2}$ で，1kgあたりでは生産 $280 \mathrm{~g}-\mathrm{CO}_{2}$, 輸送で約 $130 \mathrm{~g}-\mathrm{CO}_{2}$ を 排出している.

(2)品目別では, 重量あたりの $\mathrm{CO}_{2}$ 排出量は根菜類で 少なく, 果菜類で多い.

(3)地域別に見ると野菜輸送の平均 $\mathrm{CO}_{2}$ 排出量が最も 低いのは北海道であり，域内自給率が高ければ平均輸 送 $\mathrm{CO}_{2}$ 排出量が低くなる傾向がみられた.

(4)時期別ではいわゆる旬の時期での消費が他の時期 と比べおおむね最も $\mathrm{CO}_{2}$ 排出量が低い.

(5)輸入による輸送 $\mathrm{CO}_{2}$ 排出量は輸入相手国内の輸送 を除くと国内産品の約1.2倍である.

(6)栄養素を機能単位としてみると，ビタミンAでは 14品目中において含有量の多い野菜が環境効率も高い. ビタミンA，Cにおいてにんじんやだいこん（葉）の 効率が高く, ビタミンC, カリウムではばれいしょや だいこん（葉）の効率が高い．

今後は, 推計方法として, 消費地域別に集計した卸 売市場データではなく, 都道府県別により正確な值を 得られる個々の市場データを用いることや，用途別の 
需要に関してさらに正確な予測を行うことが課題とし て挙げられる. 栄養素関連の分析においては調理によ る影響を考慮に入れた上で指標化を行う必要がある.

さらに，本稿では環境負荷に関する現状分析に留ま っているが, 輸送の効率化や環境保全農業による環境 負荷の削減効果についても議論する必要がある.

\section{参考文献}

1）農業環境技術研究所 : 環境影響評価のためのライフサイク ルアセスメント手法の開発 研究成果報告書,

2003.

2）資源協会編 : 家庭生活のライフサイクルエネルギー, 1994.

3）久守藤男: : 食システムのエネルギー分析 LCA視点によ る, 日本エネルギー学会誌，Vol. 82 , No. 1, ppl-35, 2003.

4）根本志保子 : フードマイルズにみる生鯘野菜消費の変化と 環境負荷, 生活経済学研究第22巻・第23巻, 2006 .

5）農林水産省:野菜生産出荷統計, 農林水産省, 2004.

6）農林水産省:食料需給表（平成15年度版），2005.

7）農林水産省:野菜・果樹品目別統計（平成15年産），農林 水産省, 2004.

8）総務省編: 平成12(2000)年産業連関表, 総務省編, 2004.

9）農林水産省:農業物価統計，農林水産省，2005.

10）環境省 : 地球温暖化対策の推進に関する法律施行令で定 める排出係数一覧, 環境省, 2002.

11）南齋規介, 森口祐一, 東野達 : 産業連関表による環境負 荷原単位データブック（3EID）－LCAのインベントリデータと して一, (独)国立環境研究所 地球環境センター, 2002. (http://www-cger. nies. go. jp/publication/D031/index-j. html).
12）農林水産省 : 青果物産地別卸売統計，2004.

13）財団法人運輸政策研究機構 : 第 7 回全国貨物純流動調

查, 2002 .

14）地図ソフト ゼンリン電子地図帳 Z Professional.

15）海上保安庁 : 距離表, 2003.

16）全日本空輸(ANA)ホームページ(http://www. ana. co. jp).

17）日本航空(JAL)ホームページ(http://www. jal.co. jp).

18）交通関保エネルギー要覧，国土交通省，2004.

19）財団法人シップ・アンド・オーシャン財団 : 平成12年度 船舶からの温室効果ガス $\left(\mathrm{CO}_{2}\right.$ 等 $)$ の排出量削減に関する調査 研究報告書 平成13年6月, 2003.

20）総務省 : 家計調查年報, 2004.

21）総務省 : 住民基本台帳に基づく人口・人口動態及び世帯 数, 2003 .

22）農林水産省: 青果物卸売市場調査報告, 2004.

23）小林茂典: 野菜の品目別需給分析, 農林水産政策研究成 果情報, No. 3, 2004.

24）経済産業省 : 平成14年工業統計調查, 2004.

25) 農林水産省：じやがいもの用途別需要量の推移, 農林水 産省 さつまいも\&じやがいも ホームページ

(http://www. maff. go. jp/soshiki/nousan/imo/imoruihanindex. ht $\mathrm{ml})$.

26）文部科学省科学技術・学術審議会資源調查分科会 : 増補 五訂日本食品標淮成分表, 2005

(http://www. mext. go. jp/b_menu/shingi/gijyutu/gi jyutu3/toushi $\mathrm{n} / 05031802 . \mathrm{htm})$.

\title{
THE QUANTITATIVE EVALUATION OF ENVIRONMENTAL LOAD ON PRODUCTION AND TRANSPORTATION OF VEGETABLES
}

\author{
Naoki YOSHIKAWA, Koji AMANO and Koji SHIMADA
}

In order to obtain an in-depth understanding of the environmental load caused by the production and transportation of the vegetables consumed in Japan, we estimated the quantity of direct and indirect carbon dioxide emissions for 14 different kinds of vegetables at different times of the year and in different regions. Then we compared environmental efficiency of vegetables as $\mathrm{CO}_{2}$ emissions per vitamin and mineral content .We based our estimations on vegetable production costs and data collected from surveys conducted in the wholesale market and international trade. We estimated the $\mathrm{CO}_{2}$ emissions associated with the production and transportation of vegetables grown in Japan to be approximately 5.8 million tons per year. One kilogram of vegetables emitted 280 grams of $\mathrm{CO}_{2}$ in production and 130 grams in transportation. Root vegetables had relatively low $\mathrm{CO}_{2}$ emissions, while fruit vegetables showed higher $\mathrm{CO}_{2}$ emissions. There was a clear tendency for the vegetables produced in regions with higher vegetable self-sufficiency to create less $\mathrm{CO}_{2}$ emissions. Transportation of one kilogram of imported vegetables created approximately $20 \%$ more $\mathrm{CO}_{2}$ emissions in average than that of domestically produced vegetables. $\mathrm{CO}_{2}$ emission per vitamin $\mathrm{A}$ content of each vegetable is low in carrots and leaves of Japanese radish., $\mathrm{CO}_{2}$ emissions per vitamin $\mathrm{C}$ and kalium content are low in Irish potatoes and leaves of Japanese radish.. 